Doktor Georg Faust, posiadłszy na niemieckich uniwersytetach wszelką wiedzę, jaka była komukolwiek dostępna, udał się około roku 1515 do Krakowa, aby opanować arkana magii i alchemii, przywoływania umarłych i przewidywania przyszłości. Gdzie zawarł pakt z diabłem - nie wiadomo. Jak słusznie przypuszcza Christopher Marlowe, mógł to zrobić wszędzie, zważywszy na wszechobecność grzechu. Pierwsze pertraktacje toczyły się w Collegium Maius, gdzie jeszcze przed pół wiekiem można było oglądać ślad szatańskiej łapy, wypalony na stole alchemika. Należała ona - kto wie? - do piekielnego psa Mefista, w którego paszczy zginął jak wiadomo, potępiony doktor. Wcześniej jednak żądza potęgi, libido dominandi, pchnęła go w podróże po świecie i w zaświaty. Gdy był już gotów się nawrócić, szatan skusił go ponownym paktem (uciszywszy wyrzuty sumienia czarodziejską muzyką, dodekafoniczną zapewne, jeśli wierzyć Tomaszowi Mannowi), ofiarowując mu Helenę, najpiękniejszą kobietę starożytności. Zakochany Faust ożenił się z cieniem i zmarł w drżeniu i trwodze, wyznając uczniom tragiczną prawdę własnego życia. Faust skupia w sobie myśli i przeczucia "decydujące dla cywilizacyjnego zwrotu, jaki miał miejsce w XVI stuleciu”. Fascynacja alchemią miała doprowadzić do transmutacji złota, do rozbicia atomu. W opowiadaniu o szatańskim zaprzańcu rozpasanie intelektu, złączone z wyuzdaniem zmysłow, zyskało nowy wymiar, który umożliwił tysięczne przekształcenia i przemiany wittenberskiego doktora.

A. Szczeklik, Nieśmiertelność, s. 38-39. 



\title{
MIEJSCE FENOMENU ŚMIERCI W ONTOLOGII FUNDAMENTALNEJ MARTINA HEIDEGGERA
}

\author{
Pamięci Krzysztofa Michalskiego, \\ którego Heidegger i filozofia współczesna \\ pozwoliło mi w młodości lepiej zrozumieć \\ przepastna myśl Heideggera ${ }^{1}$.
}

\section{Wprowadzenie}

Ukazanie się Bycia i czasu² w 1927 roku stanowiło prawdziwą rewolucję w dziejach europejskiej filozofii. Przyczyniło się bowiem do powstania całego prądu kulturowego, dla którego dzieło to miało charakter niemal Pisma Świętego. Mam na myśli egzystencjalizm, który zatriumfował wprawdzie dopiero po drugiej wojnie światowej, i to dzięki nie tylko filozofii, ale także literaturze, i to raczej we Francji (Sartre, Camus) niźli w Niemczech (gdzie obok Heideggera wkład w jego powstanie miał Karl Jaspers). Egzystencjalizm nie byłby jednak niemożliwy, w faktycznie zaistniałej postaci, bez kanonicznego dzieła Heideggera. W ten oto sposób analiza egzystencji, którą Heidegger w tym dziele przeprowadza, uczyniła zeń klasyka egzystencjalizmu jako dominującego przez pewien czas nurtu intelektualnego, a nawet pewnej mody. I to mimo że sam Heidegger stanowczo się od związków z tym

${ }^{1}$ Prof. K. Michalski, wybitny znawca fenomenologii i hermeneutyki, założyciel wiedeńskiego Instytutu Nauk o Człowieku, którego stypendystą miałem zaszczyt być w 1995 roku.

2 M. Heidegger, Bycie i czas, przeł. B. Baran, Wydawnictwo Naukowe PWN, Warszawa 1994. 
prądem dystansował, mówiąc, choćby w Liście o humanizmie $e^{3}$ iż nie to było jego zamiarem.

Innym kierunkiem filozofii, który powołuje się na to klasyczne już dzieło Heideggera, jest filozofia hermeneutyczna. Dzieje się tak z dwóch powodów. Po pierwsze, $\mathrm{w}$ rozprawie tej uwidacznia się kluczowa rola rozumienia jako kategorii, która detronizuje poznanie, sugerując zakorzenienie epistemologii/teorii wiedzy (głównego zadania całej nowożytnej filozofii, od Kartezjusza po Husserla) $w$ hermeneutyce, czy też precyzyjniej: $w$ filozofii hermeneutycznej. Po drugie zaś, sam termin „hermeneutyka” pojawia się w dziele Heideggera $w$ bardzo istotnym miejscu - we wprowadzeniu. Heidegger pisze tam, iż jego zamiarem jest „hermeneutyka faktyczności”, tzn. taka analiza egzystencji, której efektem będzie ontologia fundamentalna. Analiza egzystencji to analiza ludzkiej przytomności światu - sądzę, iż zaproponowane przez nieodżałowanego Krzysztofa Michalskiego słowo „przytomność” (czy też "byt przytomny") najlepiej oddaje znaczenie Heideggerowskiego Dasein - analiza rozumiejąca, kierująca się pewną ideą tego, czym taka egzystencja się charakteryzuje, na przykład w odróżnieniu od bycia rzeczy, kamienia czy rośliny. I w tym sensie - jako rozumiejąca analiza bytu ludzkiego/ludzkiego sposobu istnienia - jest ona „hermeneutyką faktyczności”. Faktyczność - niemająca nic wspólnego z „byciem faktem”, np. w znaczeniu, którym posługuje się Wittgenstein w Tractatusie ${ }^{4}$ jest bowiem wyróżnikiem ludzkiej postaci egzystowania. $\mathrm{O}$ tym, jak wiąże się z tym trzeci element tej układanki, a mianowicie ontologia fundamentalna, powiemy w dalszej części niniejszego tekstu.

W obu tych identyfikacyjnych przypadkach pojęcie śmierci gra niezwykle istotną rolę: $\mathrm{w}$ przypadku Sartre'a pozytywną, wręcz konstytutywną (uświadamiana śmiertelność wprowadza prawdziwą egzystencjalną grozę), w przypadku Gadamera - negatywną (sygnalizowaną przez śmierć skończoność bytu ludzkiego można, jego zdaniem, odczuć i wykazać dużo prościej, niż uczynił to jego mistrz: na granice naszej mocy natrafiamy choćby w odmienności innego człowieka, w niekontrolowaniu zjawisk naturalnych, etc.). Gadamer, nawiązując z pewnością do dystansowania się Heideggera od egzystencjalizmu, odrzuca egzystencjalistyczne środki filozoficznej perswazji. Pokazuje przez to, iż jego hermeneutyka nie potrzebuje tego rodzaju egzystencjalnych podpórek, jakie oferuje pojęcie śmierci. Rewiduje przez to również - albo przynajmniej poddaje pod namysł - twierdzenie, iż Sein und Zeit jest dziełem par excellence hermeneutycznym: wyłożeniem przemyślanej

3 Tenże, List o humanizmie, przeł. J. Tischner, [w:] tenże, Znaki drogi, Fundacja Aletheia, Warszawa 1995, s. 129-168.

${ }^{4}$ L. Wittgenstein, Tractatus logico-philosophicus, PWN, Warszawa 1970. 
filozofii hermeneutycznej. Na to, że Heidegger w późniejszych latach explicite dystansował się od uznawania swego dorobku filozoficznego za stricte hermeneutyczny, wskazują jego wypowiedzi, w których wyraźnie stwierdza, iż hermetyka to "sprawa/troska Gadamera”. Jeśli zatem ani egzystencjalizm, ani hermeneutyka nie była zamiarem Heideggera, to rodzi się pytanie o intencje jego klasycznej pracy. I w tym kontekście szczególnego znaczenia nabiera pytanie o to, jaka jest funkcja fenomenu śmierci w ontologii, którą sam określił mianem fundamentalnej.

\section{Hermeneutyka faktyczności jako ontologia fundamentalna}

Szukanie rozwiązania tej kwestii zacząć należy od przypomnienia, iż Bycie i czas jest konsekwencją pewnego, zdaniem Heideggera, fundamentalnego odkrycia: odkrycia znaczenia kwestii bycia oraz zapomnienia o tej kwestii, charakteryzującego całą filozofię europejską, od Platona po Husserla. Sein und Zeit ma zatem ponownie postawić tę kwestię, jako pytanie o sens bycia. Nie: bycia ludzkiego, lecz bycia w ogóle. Takie są zapowiedzi, które znajdziemy na pierwszych kartach tego dzieła. Zapowiedzi niezrealizowane, bowiem Heideggerowi na niemal 500 stronach udaje się jedynie odsłonić sens/strukturę „przytomności” w przywołanym wyżej znaczeniu. Oczywiście nie można tego uważać za klęskę, bowiem prymat analizy egzystencji nie jest przypadkowy. Wręcz przeciwnie - jest dobrze ugruntowany, o czym za chwilę. Jeśli przyjrzymy się spisowi treści, zauważymy, iż Heidegger sygnalizuje w nim część pierwszą, która jednak okazuje się częścią jedyną. Drugiej bowiem brak. I nigdy się nie ukazała, choć pewne rozprawy napisane przezeń po ukazaniu się Bycia $i$ czasu uchodzą - słusznie lub nie - za elementy tej nienapisanej części drugiej. Tytuł części pierwszej: Interpretacja jestestwa [przytomności/bytu przytomnego - przyp. A.P.] ze względu na czasowość i eksplikacja czasu jako transcedentalnego horyzontu pytania o bycie, sygnalizuje zarazem problem, który udało się Heideggerowi podjąć i częściowo przynajmniej rozwiązać. Część ta składa się z dwóch elementów: działu pierwszego, będącego "przygotowawczą analizą fundamentalną Dasein”, oraz działu drugiego, omawiającego relację Dasein (tj. przytomności) do czasowości.

W przygotowawczej analizie przytomności dominuje metaforyka przestrzenna. Jej kulminacją jest określenie egzystencji jako „bycia-w-świecie”. Nie jest to jednak proste istnienie, znajdowanie się pewnego bytu w rzeczywistości pojętej jako ogół bytów: przedmiotów, organizmów, ludzi. Bowiem „świat” to nie termin na określenie czegoś takiego, lecz coś, czego „posiadanie" wyróżnia byt ludzki. To człowiek "ma” świat (Welt), inne byty są w śro- 
dowisku (Umwelt), istnieją w świecie człowieka jako sensy, które odbiera, ale i projektuje. Dlatego Heideggerowskie rozumienie świata przekracza nawet to, co jako transcendentalną ideę świata wymyślił Kant. Świat wedle Heideggera to pewna struktura znaczących odniesien, podtrzymywana w swym istnieniu przez Dasein rozumiejące otaczającą je rzeczywistość. W tym właśnie sensie byt przytomny ,,jest-w-świecie”, inne byty są w relacji do niego „bytami wewnątrzświatowymi".

Owo "bycie-w-świecie” analizuje przy tym Heidegger drobiazgowo w trzech jego konstytutywnych aspektach: „bycia”, „bycia-w” oraz „,́́wiata”. Nie ma tu miejsca na dłuższe dywagacje na ten temat. Ważne jest jednak to, że byty jawią się nam pierwotnie nie w swym przedmiotowo-obiektywnym charakterze, lecz jako coś poręcznego, a więc coś, co coś znaczy w naszym praktycznym, codziennym życiu: jako narzędzie, zjawisko przyrodnicze, przyjaciel/wróg. Dopiero przestawienie perspektywy na czysto poznawczą zamienia je w przedmioty podlegające obiektywistycznemu, zawsze upraszczającemu, opisowi.

$\mathrm{Z}$ tego też powodu Heidegger dostrzega nie tylko wagę rozumienia, ale i coś takiego, jak "położenie” (Befindlichkeit), a wraz z nim "nastrojenie” (Stimmung) bytu ludzkiego. Sytuacyjne Dasein, znajdujące się w konkretnym położeniu, jest zawsze jakoś nastrojone, nie tylko w sensie psychologicznym („bycia-w-jakimś-nastroju”), lecz także w sensie muzycznym: „bycia-nastrojonym” na obiór czegoś (a zamkniętym na odbiór czegoś innego: odkrywaniu jednego towarzyszy wszak zawsze zakrywanie czegoś innego). Ta figura ma swój pierwowzór w zapominaniu bycia, w różnicy ontologicznej: byt, narzucając się nam, zawsze przesłania bycie, dzięki któremu jest, powodując, że o nim zapominamy. I potrzeba dopiero pewnej operacji zmiany nastawienia - właśnie pewnej redukcji fenomenologicznej - by swe spojrzenie przenieść $z$ bytu na byt. I trzeba dodatkowej redukcji, by owo bycie uchwycić esencjalnie, w jego głębokiej, istotnej strukturze i znaczeniu. Sein und Zeit jest właśnie próbą takiej istotnościowej fenomenologii. Nieskończony zasób sposobów bycia zostaje rozpoznany i ujęty w postaci głównych charakterystyk egzystencjalnych, zwanych egzystencjałami, dla odróżnienia od kategorii stosujących się do opisu rzeczywistości pozaludzkiej, oraz struktur, które owe egzystencjały tworzą.

Nasz "świat” jest zawsze wyartykułowany, niejako poetykietowany, wysłowiony. Wskazuje na to "mowa”, trzeci, obok rozumienia i nastrojenia (położenia) element konstytucji egzystencjalnej „tu-oto-bycia” (Da-Sein). Nasze egzystowanie jest rozpięte między Sobością (Selbst) a Się (das Man), tzn. między byciem-sobą a istnieniem takim, jak "się" istnieje, jak bytują inni, w całej swej przeciętności i zdominowaniu przez narzuconą rolę społeczną. Heidegger ujmuje tę różnicę przy pomocy odróżnienia egzystencji właściwej 
i egzystencji niewłaściwej. (Dawniejsze tłumaczenia oddawały jako różnicę między egzystencją autentyczną i nieautentyczną, co tylko częściowo daje się obronić). Ważne jest to, że autor Bycia i czasu wiąże z egzystencją niewłaściwą coś, co określa mianem upadania: zatracenie się w bycie. Wiąże z tym także bezproduktywną ciekawskość oraz gadaninę, której nie zależy na rozmowach istotnych, lecz jedynie na zabiciu czasu lub zaszkodzeniu innym.

Kończąc dział pierwszy swego opus magnum, Heidegger podejmuje próbę podsumowania: znalezienie takiej charakterystyki egzystencji, która zbierałaby w jedno pojęcie wszystko, co dotąd udało mu się odsłonić. I realizuje ją w pojęciu troski.

Troska nie jest zatroskaniem o coś, codziennym wiecznym zabieganiem, utrwalającym nasze upadanie w z góry określony, znany nam byt. Takie zatroskanie ma miejsce $\mathrm{w}$ jego analizach $\mathrm{w}$ pojęciu Besorgen. Natomiast troska - Sorge, jest czymś innym, strukturalnie i semantycznie dużo bardziej złożonym. Tym określeniem Heidegger pragnie ująć strukturalny całokształt ludzkiej obecności w świecie. Charakteryzując ten termin pisze: „Bycie jestestwa oznacza: antycypujące-się-bycie-już-w-(świecie) jako bycie-przy (bycie napotykanym wewnątrz świata)" ${ }^{\prime \prime}$. To złożone określenie zawiera szereg istotnych elementów: to, że byt przytomny jest pierwotnie rozumiejącym: antycypuje sens tego, co napotyka, kierując się swym zasobem wiedzy; że jest już zawsze w pewnym świecie, który projektuje sam lub przejmuje od innych (jako tradycję, kulturę, przekaz); i że w tak pojętej rzeczywistości działa, zajmując się bytami, które znajduje wewnątrz swego świata. Rzucenie (a tu: upadanie), rozumienie (a tu: możliwość rozumienia swego powołania) oraz położenie (a tu: rozmaite postaci nastrojenia) są $\mathrm{w}$ tym pojemnym określeniu troski współzawarte. W tym jej elemencie, którym jest nastrojenie, zawarte jest jednak jeszcze coś więcej: możliwość bycia właściwego, tzn. takiego, w którym Dasein jest świadome, iż "świat”, w zarysowanym wyżej sensie, spoczywa niejako na nim, na jego sensotwórczej aktywności. Pojmuje wtedy rzeczywistość nie jako zbiór gotowych już rzeczy czy interpretacji, lecz jako coś labilnego, dynamicznego, zależnego od bytu otwartego, poprzez rozumienie, na taki a nie inny semantyczny wymiar rzeczywistości. To, że pewne części tej rzeczywistość wydają się w swym znaczeniu niezależne od człowieka (np. przyroda), a inne (np. sztuka) zależne, nie zmienia tego, że wszystkie one, z rozmaitym stopniem intersubiektywności, unoszą się na barkach kultur czy społeczeństw.

Heidegger wskazuje na pewien wyróżniony nastrój, który odsłania ową sensotwórczą moc przytomności. Jest nim nastrój trwogi (Angst), odróżniany przezeń stanowczo od nieco podobnego doń nastroju lęku czy też strachu

${ }^{5}$ M. Heidegger, Bycie i czas, dz. cyt., s. 272. 
(Furcht). Strach dotyczy zawsze czegoś konkretnego: boimy się ujadającego psa, nieprzyjaznego człowieka zmierzającego ku nam niebezpiecznym narzędziem, rodzica czy nauczyciela, który zamierza nas ukarać za niestosowne zachowanie. Boimy się często. Egzystencjalna trwoga jest zaś nastrojem rzadkim, dopadającym nas bez żadnego widzialnego czy wyraźnego powodu. Nie ma bowiem owego czegoś, przed czym się trwożymy, przynajmniej w sensie jakiegoś konkretnego obiektu.

Dlatego poddanie się takiej trwodze nie jest niczym złym. To ona daje nam bowiem możliwość wyrwania się z upadania w "Się": w publiczny charakter naszej egzystencji, podporządkowujący nasze indywidualne możliwości dyktaturze opinii publicznej - temu, jak chcą nas widzieć inni. Dlatego Heidegger powiada, że ta niemająca żadnego konkretnego obiektu trwoga, "trwoży się o bycie-w-świecie" jako takie. W trwodze tonie to, co w otoczeniu poręczne; wewnątrzświatowy byt nie może nam zagwarantować oparcia, bo uświadamiamy sobie, że jest tylko naszym projektem. „Trwoga rzuca jestestwo z powrotem w to, o co się ono trwoży, w jego właściwą możność-bycia-W-świecie. Trwoga indywidualizuje $(. . .)^{\prime \prime}$.

Teraz dopiero widać, dlaczego Bycie i czas zawiera coś, co Heidegger określił mianem ontologii fundamentalnej.

Ontologia i fenomenologia nie są dwiema różnymi dyscyplinami obok innych należących do filozofii. Oba te terminy charakteryzują samą filozofię co do przedmiotu i procedury badawczej. Filozofia jest uniwersalną ontologią fenomenologiczną wychodzącą od hermeneutyki jestestwa, która jako analityka egzystencji koniec przewodniej nici wszelkiego filozoficznego zapytywania zamocowała w miejscu, z którego ono wychodzi i do którego powraca ${ }^{7}$.

To znaczy: $w$ idei egzystencji jako takiego sposobu bytowania, któremu chodzi o nie samo, i to nie w sensie nagiego przetrwania, lecz w sensie samorealizacji indywidualnego potencjału ${ }^{8}$. Filozoficznie rzetelne odsłonięcie sensu bycia Dasein prowadzi do ontologii fundamentalnej, bowiem sens bytów (choć nie samo ich istnienie) uwarunkowany jest przez struktury rozumienia dane bytowi przytomnemu (przez wychowanie) lub przezeń wytworzone.

Byt przytomny (ogół takich bytów w ich dziejowości) jest sceną, na której rzeczywistość się prezentuje, na której może zaprezentować wszystkie swe barwy. To właśnie dlatego Heidegger - starający się wyjść poza spór idealizmu z realizmem - konstatuje nieoczekiwanie, że w tym sporze racja znajduje się po stronie idealizmu, jeśli tylko nie rozumiemy go opacznie, jako

${ }^{6}$ Tamże, s. 266.

7 Tamże, s. 54.

8 Ideę egzystencji, kierująca badaniami przeprowadzonymi w Byciu i czasie, Heidegger charakteryzuje m.in. w następujący sposób: „Ideę egzystencji określaliśmy jako rozumiejącą możność bycia, której chodzi o samo jej bycie" (tamże, s. 327). 
idealizm psychologiczny (subiektywny, idealizm wytwarzania rzeczywistości w aktach podmiotu) $)^{9}$. Tu nie rzeczywistość, lecz jej sens jest tym, co zawdzięczamy bytom przytomnym. Zawdzięczmy im to dlatego, że potrafiły oderwać się od jednego jedynego sensu napotykanych bytów, wytworzyć dystans („świat”), który stwarza nowe możliwości odniesienia. „Gdy idealizm podkreśla - pisze Heidegger - że bycie i realność są tylko »W świadomości«, to znajduje tu wyraz zrozumienie, że bycia nie można wyjaśnić przez byt"10.

\section{Ontologiczne ujęcie śmierci}

Śmierć pojawia się w pierwszych paragrafach działu drugiego, poprzedzonych prezentacją wyników przygotowawczej, statycznej analizy fundamentalnej bytu przytomnego ${ }^{11}$. Określiłem ją mianem "statycznej”, ponieważ prawdziwą dynamikę egzystowania wprowadza dopiero osadzenie „bycia-w-świecie” w czasowości, potraktowanie przytomności światu jako „czasowania". Troska, jako zasada egzystencji, musi zostać zinterpretowana w ramach czasowości, aby mogła odsłonić procesualny charakter ludzkiej przytomności światu. Jak słusznie stwierdza Oliver Jahraus:

Bycie bytu przytomnego jest bezpośrednio powiązane z czasowością. Byt ten egzystuje procesualnie, egzystuje tylko wtedy, gdy operuje. Nie jest żadnym statycznym systemem, lecz dynamiczną operacją. Różnica ontologiczna uzyskuje dzięki temu dodatkowe znaczenie (...). Z perspektyw ontycznej przytomności to proces, z perspektywy ontologicznej można go ująć jako system ${ }^{12}$.

System, w którym troska reprezentuje egzystencję jako strukturalną całość, stanowiąc pewnego rodzaju naczelną zasadę.

Zadanie, które staje teraz przed Heideggerem, polega na powiązaniu poszczególnych elementów owej zasady z wymiarami czasu, co ma pokazać, iż Dasein jest dynamiczną jednością przyszłości (swej „byłości”), teraźniejszości (swego właściwego lub upadającego zaangażowania w operowanie bytami wewnątrzświatowymi) oraz przyszłości (projektowania nowych sposób rozumienia/bycia: samego siebie oraz bytów wewnątrzświatowych). Dominujący jest przy tym wymiar przyszłości, związany z rozumieniem, z Dasein jako bytem rozumiejącym, coś , jako" to a to (albo coś innego) ${ }^{13}$. To nim byt przy-

9 Tamże, s. 293.

10 Tamże.

11 Tamże, s. 45.

12 O. Jahraus, Martin Heidegger. Eine Einführung, Reclam Verlag, Stuttgart 2004, s. 125.

13 Por. M. Heidegger, Bycie i czas, dz. cyt., s. 462: „wyliczając ekstazy [czasu - przyp. A.P.] wymienialiśmy zawsze na pierwszym miejscu przyszłość. Ma to wskazywać, ze w ekstatycznej 
tomny realizuje swą istotową, choć zawsze relatywną/rzuconą wolność: od biologiczności, od dyktatu opinii publicznej, od tradycji (rozumienia czegoś jako czegoś).

Byt przytomny tym się różni od innych bytów, że jest otwartą możliwością określania się tak lub inaczej, że nie jest zdeterminowany przez fizykę, biologię czy społeczeństwo. Najbardziej skrajną możliwością Dasein jest możliwość własnej niemożliwości, tj. nieistnienia jako możliwości. A ta dana jest w pełni tylko w fenomenie śmierci. Trwoga jako nastrój, dzięki któremu skonfrontowani zostajemy z prawdą naszej egzystencji, okazuje się jednak lękiem przed czymś. Nie jest to jednak lęk przed tym czy tamtym bytem, lecz przed własnym "nie-byciem”, tzn. przed śmiercią. Byt przytomny, w chwili, gdy jego przytomność się w pełni ukształtuje, staje się świadomy kruchości swego istnienia, własnej śmiertelności. Wie, że już w chwili urodzin "jest gotowy” na śmierć, której nadejścia nie sposób przewidzieć. Dlatego poddanie się takiemu nastrojowi nie powoduje paraliżu, lecz intensyfikację egzystowania w poszukiwaniu właściwej mu samorealizacji. To poszukiwanie przybiera często postać wsłuchiwania się w głos sumienia, u którego podstaw leży egzystencjalnie ugruntowana „wola-posiadania-sumienia”. To tu, w egzystencji właściwej, a nie w nakazach i regulacjach życia społecznego, należy szukać jego źródeł.

Rzucenie w śmierć odsłania się mu bardziej źródłowo i natarczywie w położeniu trwogi. Trwoga przed śmiercią jest trwogą „przed” najbardziej własną, bezwzględną i nieprześcignioną możnością bycia. „Przed czym” tej trwogi to samo bycie-w-świecie ${ }^{14}$.

Cechą charakterystyczną ontologii fundamentalnej Heideggera jest takie powiązanie sfery życiowej (ontycznej) ze sferą ontologiczną (transcendentalną), że można wskazać na fenomeny zachodzące w tej pierwszej, które spełniają warunki wyznaczone przez tą drugą. Nie dziwi zatem, że analizując fenomen śmierci, Heidegger charakteryzuje egzystencjalne (właściwe) i powszechne (niewłaściwe) „bycie-ku-kresowi”. To drugie polega na uciekaniu przed samą myślą o własnej nieuniknionej śmierci. "Się" podpowiada bytowi przytomnemu, że „no cóż, umiera się, umierają inni, ale na mnie jeszcze nie czas”. „W tym upadającym byciu przy (...) daje o sobie znać ucieczka od nieswojości, co teraz znaczy: przed najbardziej własnym byciem ku śmier$\mathrm{ci}^{\prime \prime 15}$. Śmierć staje się jednym z wielu wewnątrzświatowych zdarzeń, napotykanych co dzień. „Się" dba o to, byśmy o niej milczeli lub mówili zdawkowo. Troszczy się o to, przemieniając trwogę w lęk przed jakimś wydarzeniem,

jedności i właściwej czasowości przyszłość ma pierwszeństwo, chociaż czasowość nie powstaje dopiero jako zestaw i następstwo ekstaz, lecz uczasawia się zawsze przy jednakowej ich pierwotności".

14 Tamże, s. 353.

15 Tamże, s. 354. 
które kiedyś pewnie nadejdzie. Ta obojętność na ową najbardziej własną możliwość wyobcowuje Dasein z samego siebie.

W odróżnieniu od tego, egzystencjalno-ontologiczne pojmowanie śmierci da się scharakteryzować następująco: „Śmierć jako kres jestestwa jest najbardziej własną, bezwzględną, pewną, a jako taka nieokreśloną, nieprześcignioną możliwością jestestwa. Śmierć jest jako kres jestestwa w byciu tego bytu ku swemu kresowi"16. Właściwe byciu ku śmierci nie oznacza naturalnie próby spowodowania dojścia tej możliwości do skutku. Oznaczałoby to próbę samobójstwa. Heidegger pisze o tym wprost ${ }^{17}$. Nie oznacza jednak także ucieczki przed nią $\mathrm{w}$ gorliwe zaangażowanie $\mathrm{w}$ byty wewnątrzświatowe, zakrywanie śmierci poprzez podporządkowanie się „Się". Właściwym egzystencjalnym odniesieniem do świadomości swego nieuniknionego kresu jest wybieganie ku śmierci, jako możliwości, projektowanie siebie (to znaczy swej egzystencji, swych zaangażowań) na ową najbardziej własną możliwość.

Wybieganie wyzwalające się ku własnej śmierci uwalnia od zatraty wśród przypadkowego natłoku możliwości (...) otwiera egzystencji jako ostateczną możliwość rezygnację z siebie i burzy w ten sposób każde zastygnięcie przy osiągniętej kiedyś egzystencji ${ }^{18}$.

Gwoli jasności można by dodać: postaci egzystencji. W takim „wybieganiu-ku-śmierci" tkwi - powiada Heidegger - możliwość żywej, ontycznej, to znaczy odczuwanej życiowo, antycypacji całości swego jestestwa.

\section{Wnioski}

Hermeneutyka faktyczności to kontynuacja fenomenologii transcendentalnej przy nieco innych założeniach wyjściowych. Również Heidegger pragnie odsłonić proces generowania znaczeń i podtrzymywania ich $\mathrm{w}$ istnieniu. Punktem wyjścia nie czyni jednak poznającej świadomości, oczyszczonej ze swego historyczno-kulturowego uwikłania, lecz żywe ludzkie istnienie, które cechuje rozumienie rzeczywistości swego życia dzięki byciu rzuconym w "Się" konkretnej kultury, języka, społeczeństwa. Heidegger jest świadom tego, że owa kultura może niekiedy zabijać jednostkową samorealizację, i dlatego nadaje swej filozofii indywidualistyczny, egzystencjalny ton. Jego hermeneutyka faktyczności staje się nie tylko opisem, ale także apelem egzystencjalnym o podjęcie trudu dotarcia do głębi samego siebie i próby realizacji egzystencji właściwej. Teoria chce tu oddziaływać na praktykę. To te apele stanowiły przyczynek do egzystencjalistycznych interpretacji ontolo-

\footnotetext{
16 Tamże, s. 363.

17 Tamże, s. 366.

18 Tamże, s. 370-371.
} 
gii fundamentalnej. Wydaje się, że można od nich abstrahować, a koncepcja Heideggera zyska na jasności i sile przekonywania. Uczynił to zresztą sam Heidegger, nie podejmując wątku egzystencjalnego w swej filozofii w latach późniejszych.

Stwierdzenie, przywołane przy okazji oceny sporu idealizmu z realizmem, mówiące, iż „bycia nie można wyjaśnić przez byt”, wskazuje na to, iż Heidegger ma świadomość transcendentalnego charakteru nie tylko swej, ale każdej porządnej filozofii: wyjaśnienie uniwersum sensu, w którym żyjemy, nie powiedzie się bez uznania transcedentalnych (tzn. przekraczających aktualne doświadczenie) ram rozumienia, które jego ontologia fundamentalna odsłoniła w postaci prestruktury rozumienia, na którą składają się „wstępny zasób" (wyjściowa wiedza umożliwiająca rozumienie danego obszaru bytu, lepsza lub gorsza), ",wstępny ogląd” (perspektywa, z której coś ujmujemy) $\mathrm{i}$ „wstępne pojęcie” (aparat kategorialny, który w danym momencie mamy do dyspozycji) ${ }^{19}$.

Ontologia fundamentalna otwiera nowy rozdział w dziejach fenomenologii. Wskazuje na to bardzo silnie zastosowanie terminu Dasein, nie bez kozery tłumaczonego jako przytomność, a nie jako jestestwo. Określenie „jestestwo” wskazuje na pewien byt, nawet jeśli jest to byt jakoś wyróżniony. Przytomność wskazuje natomiast na pewien sposób bycia. A przecież nieprzypadkowo Heidegger wybiera termin Da-Sein, którego częścią jest „bycie” (Sein), a nie "byt” (Seiendes). Dlatego też, w świetle przyjętej tu wykładni, Sein und Zeit jest, jak wyżej powiedziano, realizacją - co prawda niedokończoną pewnego projektu, który można by określić mianem fenomenologii hermeneutycznej. Fenomenologią jest ona w tym znaczeniu, iż punktem wyjścia jest próba uchwycenia zjawisk stanowiących żywe doświadczenie człowieka, i to zarówno w sensie potocznym, jak i głębszym. Dlatego zawiera elementy metodyczne, które to umożliwiają. Na niektóre z nich wskazywaliśmy wyżej. Natomiast na przymiotnik „hermeneutyczna” zasługuje z uwagi na odrzucenie pewnych dogmatów fenomenologii Husserla, będącej transcendentalną teorią czystej świadomości. Heidegger porzuca świadomość na rzecz przytomności. Ta przytomność jest zawsze „byciem-w-świecie”, „rzuceniem" w pewną określoną już rzeczywistość, uprzytomnianiem jej sobie, znajdowaniem się pewnej sytuacji, na która świadomość reaguje, daleka od panowania na nią. Jest to więc istnienie w pewnym uniwersum sensu, generowanym przez fakt rzucenia $\mathrm{w}$ określoną rzeczywistość przyrodniczą, kulturową i społeczną ${ }^{20}$. Odrzuca więc Heidegger postulat bezzałożenio-

19 Tamże, § 31 i 32 .

20 Przy czym samo rozdzielenie tych rzeczywistości jest wtórne, bowiem pierwotnie rzeczywistość dana nam jest w niezróżnicowaniu, jako „rzeczy-wistość”, co jeszcze lepiej oddaje niemiecki termin Wirklichkeit, oparty na rdzeniu wirken - „oddziaływać na coś”. 
wości, przyjmuje obecność wstępnej wiedzy (owego Vorhabe z prestruktury rozumienia). Przyjmuje także, że świadomość jest pochodną tak rozumianej przytomności oraz że analiza tak pojętego „bycia-w-świecie” (tj. egzystowania) ma charakter interpretacji, wychodzącej od pewnej idei egzystencji. Jest więc pewnego rodzaju "hermeneutyką": rozumiejącą analizą bytu rzuconego w egzystowanie. Wszystko to prowadzi do tezy, iż dokonując korekty koncepcji swego starszego kolegi - bo Husserl nie był, jak się zdaje, nigdy dlań mistrzem - Heidegger był ukształtowanym myślicielem w chwili dołączenia do Husserla ${ }^{21}$; Heidegger stworzył koncepcje nowej, hermeneutycznej fenomenologii, którą na swój sposób rozwijali dwaj wybitni hermeneuci: Gadamer i Ricoeur ${ }^{22}$.

Maciej Potępa pokazał, iż krytyki Heideggerowskiego ujęcia śmierci, które wyszły spod piór Lévinasa, Sartre'a czy Schulza, są nietrafione, opierają się bowiem na błędnej interpretacji sensu i zamierzeń Heideggera związanych $\mathrm{z}$ tym pojęciem ${ }^{23}$. Konstatowany przez Léviansa, jako zarzut, brak w Heideggerowskim ujęciu śmierci elementów takich jak cielesność, cierpienie, bierność umierającego wobec tego, co nadchodzi, nie jest obiekcją uzasadnioną. Heidegger nie mówi bowiem o śmierci właśnie nadchodzącej, na przykład o umierającym starszym człowieku, lecz o tym, ze śmierć jako świadomość śmiertelności towarzyszyć powinna właściwemu zrozumienia własnej egzystencji, jako czegoś nieodwołalnie kruchego, co obliguje nas do namysłu i do pewnych wyborów. I jeśli można mieć do Heideggera pretensje, to nie o to, że nie uwzględnił cierpienia towarzyszącego bardzo często umieraniu, lecz że nie do końca wykorzystał etyczny potencjał, jaki tkwi w jego pojęciu śmierci. Mimo iż - jak wieść głosi - na pytanie studenta, kiedy do Bycia i czasu dopisze etykę, odpowiedział, że dzieło to całe jest etyką, tak naprawdę nie wyszedł poza zaczyn etyki, jakim była „wola-posiadania-sumienia”. Późniejsze quasi-etyczne dywagacje zaciemniły nawet ten element ${ }^{24}$.

Ale nawet jeśli uznać trafność diagnozy tego warszawskiego hermeneuty, to i tak warto się zastanowić nad elementami opisu fenomenu śmierci, które

${ }^{21}$ Piszę o tym w książce W poszukiwaniu królestwa filozofii: z dziejów neokantyzmu badeńskiego, Wydawnictwo Naukowe UAM, Poznań 2004, gdzie analizuję wczesne prace Heideggera oraz wskazuję na ich związek z filozofią badeńskich neokantystów, w szczególności Emila Laski.

${ }^{22}$ To, jak czynił to Gadamer, odsłaniam w kilku swych tekstach, min. w: O fenomenologii w hermeneutyce, czyli Gadamerowska krytyka Husserla, [w:] A. Przyłębski (red.), Dziedzictwo Gadamera, Wydawnictwo Fundacji „Humaniora”, Poznań 2004, s. 169-188. W przypadku Ricoeura, instruktywny jest tutaj zwłaszcza tekst Fenomenologia i hermeneutyka. Wychodzac od Husserla, [w:] J. Migasiński, I. Lorenc (red.), Fenomenologia francuska: rozpoznanie, interpretacja, rozwinięcia, Wydawnictwo Instytutu Filozofii i Socjologii PAN, Warszawa 2006, s. 194 i n.

${ }^{23}$ M. Potępa, Fenomenologia faktycznego życia: Martin Heidegger, Genessis, Warszawa 2004, s. 267-292.

${ }^{24}$ Piszę o tym szerzej, polemizując z P. Dyblem, w książce: Etyka w świetle hermeneutyki, Oficyna Naukowa, Warszawa 2010. 
są dziełem wyżej wymienionych. Bo nieuwzględnienie cielesnego aspektu ludzkiej egzystencji, na co zwraca uwagę nie tylko Lévinas, ma istotne znacznie dla uznania ontologii fundamentalnej za zadowalającą, całościową analizę egzystencji. Opracowanie tego musimy pozostawić jednak na inną okazję, podobnie jak charakterystykę tego, jak filozofie hermeneutyczne Gadamera i Ricoeura, nawiązujące do Heideggera pozytywnie, odniosły się do fenomenu „bycia-ku-śmierci”.

\title{
The place of the phenomenon of death in Heidegger's fundamental ontology
}

\author{
Sum mary
}

The text begins with an introduction that sketches the philosophical and cultural context of Being and Time which is followed by three parts. In the first part the author explains the reasons why Heidegger's analysis of human existence, which he calls a "hermeneutics of facticity", developed into fundamental ontology. In the second part the author discovers an ontological description of death, as contained in this book, which is fundamentally different from any ontic description of this phenomenon. The last part contains the conclusions: 1 . Heidegger's fundamental ontology opens up a new chapter in the history of Western philosophy; it is an original project of a hermeneutic phenomenology; 2. the experience of death belongs, according to Heidegger, to the transcendental structure of a human being. Levinas's and Sartre's critique of Heidegger's description of death is invalid because Heidegger does not describe bodily experience and pain, which accompany the process of dying, but rather the consciousness of being mortal that conditions people's existential projects. This constitutes a deeper sense of his analyses. 